\title{
Impact of Distance Learning through Zoom Application and WhatsApp Group on Students' Attitude and English Aptitude: A Case Study on Students of ICT due to Covid-19 Outbreak
}

\author{
Author \\ Fujiono (Orcid ID. 0000-0001-6722-6723), \\ Paulina (Orcid ID. 0000-0003-4968-4901), \\ Nurul Hidayat (Orcid ID. 0000-0001-7735-9132), \\ Farah Natchiar Binti Mohd Khaja (Orcid ID. 0000-0003-3311-5501) \\ Correspondence \\ Universitas Madura, Jawa Timur, Indonesia \\ Universitas Muhammadiyah Gresik, Jawa Timur, Indonesia \\ Universitas Pendidikan Sultan Idris, Malaysia \\ fujiono@unira.ac.id,nurul@unira.ac.id
}

\begin{abstract}
This study was a case study of qualitative research design to know the impact of distance learning through zoom application and WhatsApp group on students' attitude and English aptitude: A Case Study on Students of ICT due to Covid-19 Outbreak. The study showed that most of the students' attitude or response to online learning using zoom application is less attractive, interactive, effective, efficient and energetic. It found that many troubles with their signal, and they often got limited internet package. Zoom meeting needed a much internet package to connect between lecturer and learners in one appointment. In this case, the trouble networks and limited internet also often impacted students' learning process, style, and strategy to enhance their English aptitude, listening and speaking competency.

Meanwhile, the lecturer took the usage of the WhatsApp group by sending voice notes and materials about reading and writing. No troubled networks to download and upload the reading and writing tasks during distance teaching and learning class. It needed a little internet to get the online materials. Based on the situation, almost all participants felt interesting to join the reading and writing online course. Aside from that, they could enhance their English aptitude; reading and writing proficiency. To against the highly infectious covid-19 pandemic, distance learning has created physical and mental health from fear, anxiety, panic, and influenza outbreaks. Learning from home is one of the solutions to reduce physical contact with many people. Therefore, distance learning has been referred to save the educational young generation from the pandemic of the covid-19 outbreak.
\end{abstract}

Keywords : Distance Learning, StudentsAttitude, English Aptitude, Covid 19 Outbreak.

Received: 15 June 2021. Accepted: 24 June 2021

\section{Introduction}

The covid-19 outbreak has brought up a big significant effect on every sector for economic, industry, and global education. Not only among them but also it threatened the lives of human across the wide world. For example,. Di Pietro, Biagi, Costa, Karpiński, \& Mazza (2020) ) stated that million students broke up their school learning around the world during the pandemic, and intimidated their upcoming education authority.

This policy was created as an attempt to anticipate the spread of the covid-19 outbreak.
To avoid the intimidation of future education, Indonesia has created a policy to overcome education problems as long as the Covid-19 outbreak. Learning in class or face to face learning has changed into distance learning. During the pandemic of covid-19, language learning becomes a prior error to acquire a foreign language. Therefore, the EFL learners studied English without direct contact or interaction, Even though English can be easier to learn through direct interaction. Therefore, based on the situation, they are ordered to study English in their home to reduce physical contact or 
interaction among students in this situation, coronavirus disease or covid-19 has afflicted Indonesia.

The teacher needs to be aware to implement the technology such as zoom application and WhatsApp group as online learning media in the mid of the covid-19 pandemic. (Lick \& Kaufman (2011) stated that the technology offers an enormous chance to enhance the effectiveness and efficiency of distance learning in the future.

Distance learning is not only driven by technology, but It is also encouraged by professional obligation to educate or teach the learners (Winkelmann, 2019).

Some advantages of distance teaching and learning during lockdown period, the lecturerlearners can implement instructional English materials through dissimilar channel like zoom application, google classroom, WhatsApp group, Telegram group, etc.

In distance teaching and learning, the teacher can design, develop, and deliver listening, speaking, reading, and writing skills. Zoom application as distance learning media can be used for listening and speaking online class. While, WhatsApp group can be used for reading and writing online class. Those tools were found to be an easy and effective media which was accessible for online learning (Suriyani Djamdjuri \& Kamilah, 2020). they also help in increasing closeness and connection not only in informal contexts, but also in distance learning contexts, even facilitating reflection, coordination, identification and, in some cases, with student control and ownership (Gachago, Strydom, Hanekom, Simons, \& Walters, 2015).

Therefore, the researcher was interested to research "Impact of Distance Learning through Zoom Application and WhatsApp Group on Students' Attitude and English Aptitude: A Case Study on Students of ICT due Covid-19 Outbreak".

\section{Methods}

The study method approach was a case study. Employing a case study, this research attempts to portrait or describe the impact of distance learning through Zoom Application and WhatsApp Group on the students' attitude and English aptitude as long as Covid-19 outbreak.

According to James James (2015), a case study is one of qualitative research to find out a meaning, search a process, and understand in depth. In this research, the source of data included questionnaire results and directly observation. While, the participants were college learners. To analyze the data, the researcher reduced, displayed, and verified the data.

In this current issues, the Covid-19 Outbreak is more growing up. Therefore, several governments including Indonesia has referred the school learning to be online learning or distance learning to break out the transmission of the Covid-19.

To assess the student's need, the teacher must be proactive, creative, and energetic to teach the students efficiently and effectively through online learning. Home learning can be formal class due covid-19 outbreak. Learning at home is a literacy activity to finish a target of learning curriculum. Unfortunately, during online learning, the students have less motivation to learn and complete their tasks.

Based on the observation and questionnaire results, they were seeing forward to learn in the class. However, they also felt too many tasks from the lecturer to finish. This learning has an impact on their attitude and English aptitude. Here the results of the questionnaire:

The results of the student's response to the distance learning through zoom application and WhatsApp group 


\begin{tabular}{|l|l|c|c|c|c|}
\hline No & \multicolumn{1}{|c|}{ Questionnaire } & \multicolumn{3}{|c|}{ Selection } \\
\hline 1 & $\begin{array}{l}\text { Are you interested in } \\
\text { learning English through } \\
\text { Zoom Meeting? }\end{array}$ & $\begin{array}{c}\text { Very } \\
\text { interested } \\
(26 \%)\end{array}$ & $\begin{array}{c}\text { Interested } \\
(18 \%)\end{array}$ & $\begin{array}{c}\text { Slightly } \\
\text { interested } \\
(45 \%)\end{array}$ & $\begin{array}{c}\text { Not } \\
\text { Interested } \\
(11 \%)\end{array}$ \\
\hline 2 & $\begin{array}{l}\text { Are you interested in } \\
\text { learning English through } \\
\text { WhatsApp Group? }\end{array}$ & $\begin{array}{c}\text { Very } \\
\text { interested } \\
(32 \%)\end{array}$ & $\begin{array}{c}\text { Interested } \\
(42 \%)\end{array}$ & $\begin{array}{c}\text { Slightly } \\
\text { interested } \\
(18 \%)\end{array}$ & $\begin{array}{c}\text { Not } \\
\text { Interested } \\
(8 \%)\end{array}$ \\
\hline 3 & $\begin{array}{l}\text { Do you experience unstable } \\
\text { signal interference during } \\
\text { online learning? }\end{array}$ & $\begin{array}{c}\text { Always } \\
(24 \%)\end{array}$ & $\begin{array}{c}\text { Often } \\
(34 \%)\end{array}$ & $\begin{array}{c}\text { Sometimes } \\
(26 \%)\end{array}$ & $\begin{array}{c}\text { Never } \\
(16 \%)\end{array}$ \\
\hline 4 & $\begin{array}{l}\text { Do you experience } \\
\text { problems with limited } \\
\text { internet packages while } \\
\text { studying online? }\end{array}$ & $\begin{array}{c}\text { Always } \\
(29 \%)\end{array}$ & $\begin{array}{c}\text { Often } \\
(40 \%)\end{array}$ & $\begin{array}{c}\text { Sometimes } \\
(18 \%)\end{array}$ & $\begin{array}{c}\text { Never } \\
(13 \%)\end{array}$ \\
\hline 5 & $\begin{array}{l}\text { How is your listening skill } \\
\text { through zoom meeting? }\end{array}$ & $\begin{array}{c}\text { Greatly } \\
\text { improved } \\
(16 \%)\end{array}$ & $\begin{array}{c}\text { Increase } \\
(24 \%)\end{array}$ & $\begin{array}{c}\text { Less } \\
\text { increase } \\
(42 \%)\end{array}$ & $\begin{array}{c}\text { Not } \\
\text { increase } \\
(18 \%)\end{array}$ \\
\hline 6 & $\begin{array}{l}\text { How is your speaking skill } \\
\text { through zoom meeting }\end{array}$ & $\begin{array}{c}\text { Greatly } \\
\text { improved } \\
(18 \%)\end{array}$ & $\begin{array}{c}\text { Increase } \\
(26 \%)\end{array}$ & $\begin{array}{c}\text { Less } \\
\text { increase } \\
(40 \%)\end{array}$ & $\begin{array}{c}\text { Not } \\
\text { increase } \\
(16 \%)\end{array}$ \\
\hline 7 & $\begin{array}{l}\text { How is your reading ability } \\
\text { through WhatsApp Group? }\end{array}$ & $\begin{array}{c}\text { Greatly } \\
\text { improved } \\
(47 \%)\end{array}$ & $\begin{array}{c}\text { Increase } \\
(32 \%)\end{array}$ & $\begin{array}{c}\text { Less } \\
\text { increase } \\
(13 \%)\end{array}$ & $\begin{array}{c}\text { Not } \\
\text { increase } \\
(8 \%)\end{array}$ \\
\hline 8 & $\begin{array}{l}\text { How are your writing skills } \\
\text { via WhatsApp Group? }\end{array}$ & $\begin{array}{c}\text { Greatly } \\
\text { improved } \\
(42 \%)\end{array}$ & $\begin{array}{c}\text { Increase } \\
(37 \%)\end{array}$ & $\begin{array}{c}\text { Less } \\
\text { increase } \\
(16 \%)\end{array}$ & $\begin{array}{c}\text { Not } \\
\text { increase } \\
(5 \%)\end{array}$ \\
\hline 10 & $\begin{array}{l}\text { Are you motivated to learn } \\
\text { from home, remotely or } \\
\text { online learning? }\end{array}$ & $\begin{array}{c}\text { Very } \\
\text { motivated } \\
(21 \%)\end{array}$ & $\begin{array}{c}\text { Motivated } \\
(18 \%)\end{array}$ & $\begin{array}{c}\text { Less } \\
\text { motivated } \\
(37 \%)\end{array}$ & $\begin{array}{c}\text { Not } \\
\text { motivated } \\
(24 \%)\end{array}$ \\
\hline in class? & $\begin{array}{c}\text { Very } \\
\text { anotivated } \\
(34 \%)\end{array}$ & $\begin{array}{c}\text { Motivated } \\
(29 \%)\end{array}$ & $\begin{array}{c}\text { Less } \\
\text { motivated } \\
(21 \%)\end{array}$ & $\begin{array}{c}\text { Not } \\
\text { motivated } \\
(16 \%)\end{array}$ \\
\hline
\end{tabular}

In the zoom meeting, the researcher has tried to implement listening-speaking context. Most of the students' attitudes or responses to online learning are less interesting, interactive, effective, and energetic. They had many troubles with their signal, and they often got limited internet package. Zoom meeting needed much package to connect between lecturer and learners in one meeting. In this case, the trouble networks and limited internet also often impacted students' learning process, style, and strategy to enhance English aptitude, listening and speaking competency.

In the WhatsApp group, the lecturer has sent voice notes and materials about reading and writing. During the Covid-19 outbreak, all learners and lecturers should work from home, study time at home has been formal online learning class. They ever felt anxious to isolate themselves at their 
home. Nothing no interaction in enjoyable class. Here, the researcher or lecturer implemented reading and writing materials as an additional activity to reach the target of learning curriculum.

Reading and writing expertise have become a prior target in nonlanguage department. Nothing trouble networks download and upload the reading and writing tasks during online teaching and learning. It needed a little internet to get the online materials. Based on the situation, almost all participants felt interesting to join reading and writing online class. In another case, they could enhance their English aptitude, reading and writing proficiency. It was referred to their reading and reporting scores and questionnaire results.

As long as a pandemic of covid19 outbreak. Most learners felt anxious, boring, and stress because of lockdown policy. It was described that too many tasks from lecturer through online or distance learning, it caused they want to come back into school learning normally. Based on the questionnaire results has shown that most of the participants has chosen normal class rather than online class. Besides that, the trouble networks, limited internet, and disciplinary of task sending has become an enforcement for college learners to improve their attitude and English aptitude. But, the generation or future education safety has become urgency from the transmission of covid-19 outbreak.

\section{Implication}

The research result has implication for professional lecturer and institution to apply the strategies on distance learning through Zoom Application and WhatsApp Group, and ensure the content of task suitable with the learners' need. The distance learning also creates the physical and psychological health as long as covid-19 pandemic.

\section{References}

Di Pietro, G., Biagi, F., Costa, P., Karpiński, Z., \& Mazza, J. (2020). The Likely Impact of COVID-19 on Education: Reflections based on the Existing Literature and Recent International Datasets. Publications Office of the European Union, Luxembourg.

Gachago, D., Strydom, S., Hanekom, P., Simons, S., \& Walters, S. (2015). Crossing boundaries: lecturers' perspectives on the use of whatsapp to support teaching and learning in higher education. Progressio: South African Journal for Open and Distance Learning Practice. https://doi.org/10.25159/0256$8853 / 579$

James, S. (2015). Finding Your Passion: Work and the Authentic Self. $M / C$ Journal. https://doi.org/10.5204/mcj.954

Lick, D. W., \& Kaufman, R. (2011). Change Creation for Online Learning and Technology. In Encyclopedia of Distance Learning. https://doi.org/10.4018/978-159140-555-9.ch030

Suriyani Djamdjuri, D., \& Kamilah, A. (2020). Whatsapp media in online learning during covid-19 pandemic. English journal. https://doi.org/10.32832/english.v $14 \mathrm{i} 2.3792$

Winkelmann, Z. K. (2019). Impressions of Telemedicine in Athletic Training Education. ProQuest Dissertations and Theses. 